\title{
Damage Characteristics and Mechanism of a 2010 Disastrous Groundwater Inrush Occurred at the Luotuoshan Coalmine in Wuhai, Inner Mongolia, China
}

\author{
Fangpeng Cui ${ }^{1,2, * \mathbb{D}}$, Qiang Wu ${ }^{1,2}$, Chen Xiong ${ }^{1,2, * \mathbb{D}}$, Xiang Chen ${ }^{1,2}$, Fanlan Meng ${ }^{1,2}$ and \\ Jianquan Peng 1,2 \\ 1 College of Geoscience and Surveying Engineering, China University of Mining and Technology, \\ Beijing 100083, China; wuq@cumtb.edu.cn (Q.W.); chenxiang@student.cumtb.edu.cn (X.C.); \\ meng@student.cumtb.edu.cn (F.M.); fitz_peng@student.cumtb.edu.cn (J.P.) \\ 2 National Engineering Research Center of Coal Mine Water Hazard Controlling, Beijing 100083, China \\ * Correspondence: cuifp@cumtb.edu.cn (F.C.); xiongc@student.cumtb.edu.cn (C.X.)
}

Received: 12 February 2020; Accepted: 25 February 2020; Published: 28 February 2020

\begin{abstract}
On 1 March 2010, a disastrous groundwater inrush occurred at the Luotuoshan coalmine in Wuhai (Inner Mongolia, China). Great effort was taken during the post-accident rescue. However, triggered by a large amount of groundwater rushed in from the Ordovician limestone aquifer underlying the No.16 coal seam through the fractured sandy claystone and the karst collapse column, it caused great damage, including 32 deaths and direct economic losses of over 48 million yuan. The groundwater inrush originated from the floor heave in the air return gallery of the No.16 coal seam. The peak inflow rate was $60,036 \mathrm{~m}^{3} / \mathrm{h}$. The gallery excavation under conditions caused by the incompletely recognized hydrogeological environment induced the accident. The unidentified spatial distribution of the karst collapse column triggered the accident directly. The high-pressure groundwater accumulated in the collapse column and the gallery excavation, which caused the redistribution of the in situ stress, contributing to progressive fractures in the floor of the No. 16 coal seam. Eventually, an intensive water-conductive passage consisting of the fractured floor and the karst collapse column formed. Administratively/technically, that mandatory regulations on gallery excavation were not carried out which contributed the accident. Moreover, the poor awareness about groundwater inrush recognition and quick remediation also contoirbuted to the disastrous extent of the accident.
\end{abstract}

Keywords: groundwater inrush; the Luotuoshan coalmine; damage mechanism; karst collapse column

\section{Introduction}

Underground gallery excavation and coal mining can severely influence the nearby strata. Meanwhile, the nearby hydrogeological conditions will also change seriously. As a result, groundwater inrushes into mining areas occur sometimes all over the world. Cases happening in the United Kingdom, Italy, Slovenia, Poland, Australia, India, etc., have been reported and the causes discussed [1-5]. Eventually, for mitigating their great damage, many effective methods were proposed [6-8].

In China, to meet great requirement of the rapid economic progress in recent decades, annual coal production has increased and remained at a very high level. Coalmine water inrushes have occurred sometimes during this process. Figure 1 details some properties of the groundwater inrushes from 2000. The number of the accidents and deaths obviously decreased, but unfortunately, some serious 
groundwater inrush episodes brought great damage $[9,10]$. Therefore, there is still a long way to go for their prevention.

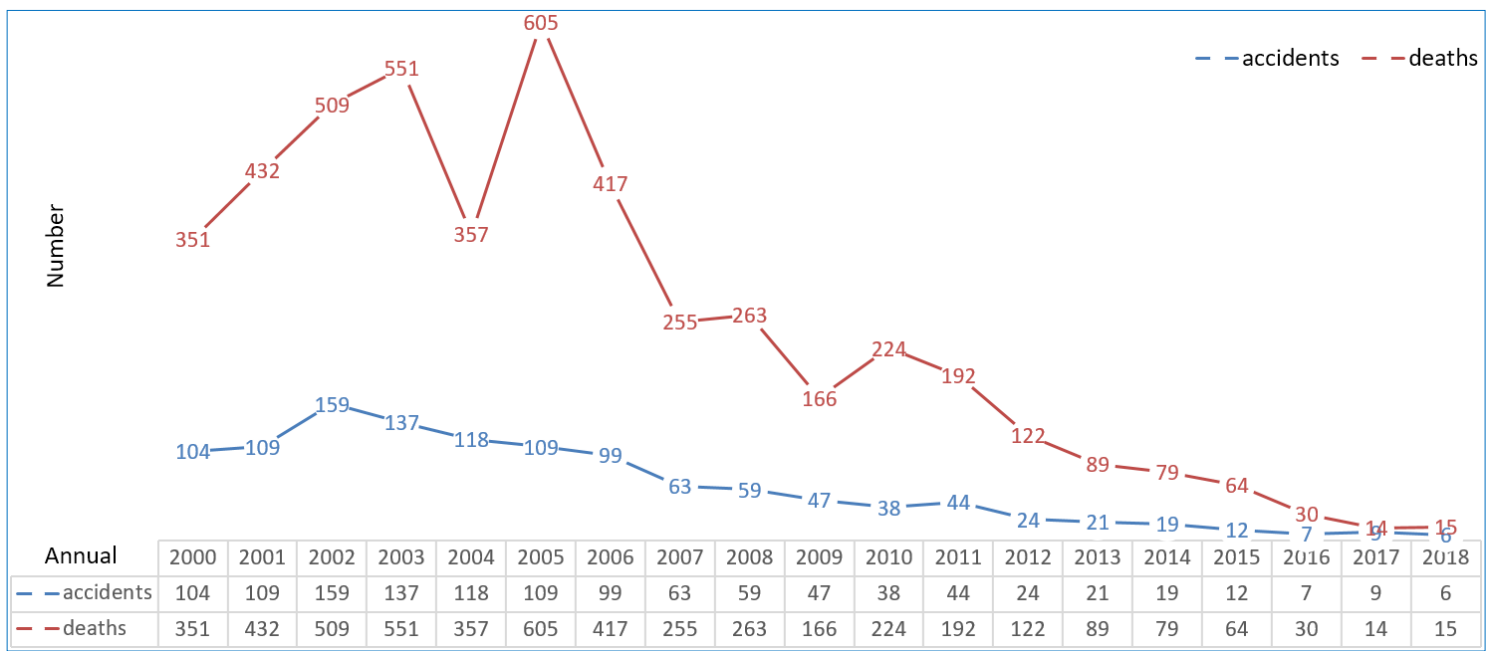

Figure 1. Characteristics of coalmine water disasters occurred in China from 2000 to 2018.

Actually, in China, a great number of related studies have been conducted. Causes, geological circumstances, categories, early recognition, forecasting, prevention and control methods for the inrushes were the focus in these studies [11-16]. Subsequently, some research-based and practice-tested techniques and methods formed gradually [17-21]. All of these effectively strengthen safety of underground coal mining operations.

Nevertheless, at 7:20 am on 1 March 2010, a disastrous groundwater inrush occurred the Luotuoshan coalmine located in Wuhai, Inner Mongolia, China. When the accident happened, the coalmine was in gallery-construction mode and 77 miners were working in galleries. Fortunately, 45 miners escaped from the accident, but 32 miners were drowned. Furthermore, the accident caused direct economic losses of over 48 million Yuan.

\section{The Coalmine}

Located in Wuhai (Figure 2), Inner Mongolia, the Luotuoshan coalmine began its construction in 2006. Its annual design capacity was 1.5 million tons of raw coal. The coalfield is about $10-\mathrm{km}$ long along the north-south direction and 4- $\mathrm{km}$ wide along the east-west direction. Its area is about $38.7 \mathrm{~km}^{2}$. The coal reserves are estimated at about 0.42 billion tons and the exploitable amount is about 0.25 billion tons.

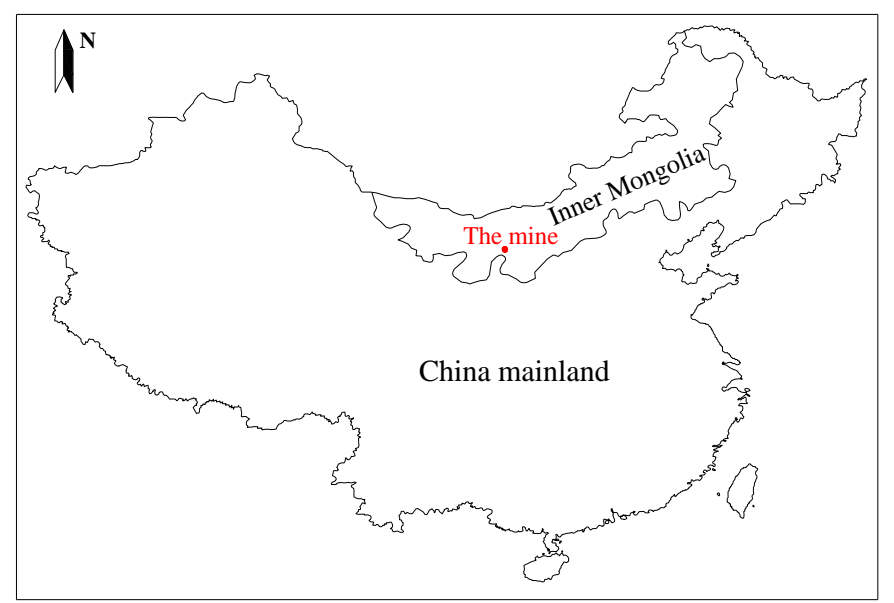

Figure 2. Location sketch of the Luotuoshan coal mine. 
Before the date of the groundwater inrush, construction of the main inclined shaft, auxiliary inclined shaft and vertical air return shaft of the coalmine had been completed. Meanwhile, construction of main galleries in the No. 9 zone and the No. 16 coal seam had been completed, too. As shown in Figure 3, at the time of the groundwater inrush, two air return galleries in the No. 9 coal seam and an air return gallery in No. 16 coal seam were under construction.

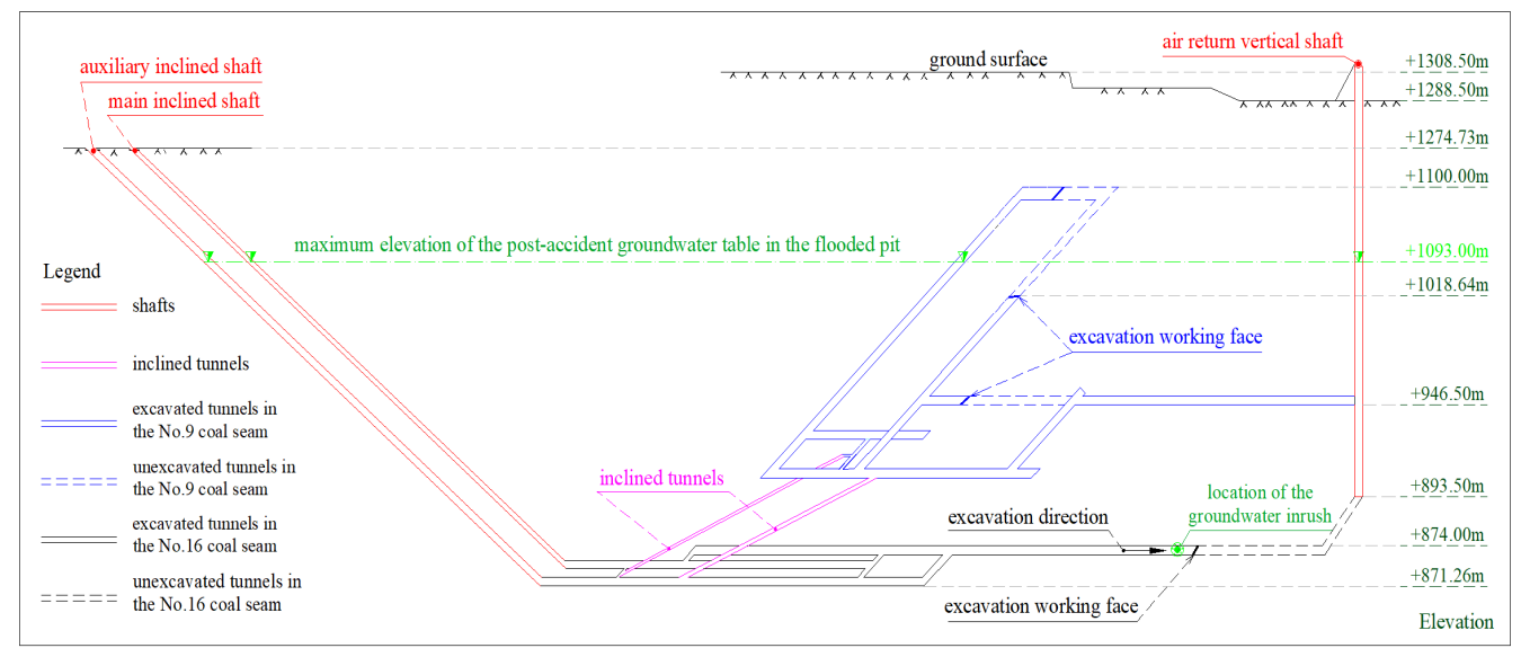

Figure 3. Distribution sketch of the shafts and galleries in the Luotuoshan pit.

\section{The Geological Setting}

The Luotuoshan coalfield is located in a semi-desert region. Mountains and valleys exist on its east and west boundary. It rains a little and a drought climate prevails. Surface runoff forms scarcely. The Yellow River passes through the west of the coalfield. Normal faults develop in the shallow ground of the coalfield.

Sand beds and gravels cover the surface. As shown in Figure 4, the formed strata in the coalfield, in chronological order, include: (1) karst limestone formed in the Ordovician Period, (2) coal seam, sandy claystone, sandstone and claystone formed in the Carboniferous Period, (3) coal seam, sandy claystone, sandstone and claystone formed in the Permian Period, (4) sandy claystone and coarse sandstone formed in the Triassic Period and, (5) sand bed and gravel formed in the Quaternary Period. Thickness of the Ordovician strata is about $200 \mathrm{~m}$. Thickness of the Carboniferous strata is about 40-100 m. Total thickness of the Permian and Triassic strata is about $236-897 \mathrm{~m}$. Thickness of the Quaternary strata is about $0-25 \mathrm{~m}$.

Coal seams in the Luotuoshan coalfield are located mainly in the Permian and the Carboniferous strata. The No. 9, the No. 10 and the No. 16 coal seam are the main minable ones. Their total thickness is about $10.41 \mathrm{~m}$. Their properties are detailed as follows: the thickness of the No. 9 coal seam varies from $0.94 \mathrm{~m}$ to $8.24 \mathrm{~m}$ and the average is about $4.32 \mathrm{~m}$. Its roof and floor are comprised of claystone. The average thickness of the No. 10 coal seam is about $0.98 \mathrm{~m}$. The average thickness of the No. 16 coal seam is about $5.13 \mathrm{~m}$. Its roof is comprised of sandy claystone, claystone and sandstone. Its floor is comprised of siltstone, fine sandstone, sandy claystone and claystone.

Based on lithological properties, three types of aquifers developed in the coalfield. They are the Quaternary porous phreatic aquifer, Permian, Carboniferous fractured sandstone confined aquifer, and Ordovician karst limestone confined aquifer.

Alluvium, diluvium, aeolian sand, loessial sand and colluvium compose the Quaternary phreatic aquifer. Its maximum total thickness is about $25 \mathrm{~m}$ and the average is about $6 \mathrm{~m}$. The alluvium and diluvium are located at the dry river valleys and terraces with different elevations. They comprise sand and gravel layers. Pores are partly filled with groundwater. The depth of the groundwater varies from 1.15 to $19.13 \mathrm{~m}$. Because of their limited distribution in space, aeolian sand, loessial sand 
and colluvium contain litter groundwater. They are recharged directly by rainfall. Meanwhile, they recharge the neighbor underlying strata.

\begin{tabular}{|c|c|c|c|c|c|}
\hline strata sy stem & $\begin{array}{l}\text { average } \\
\text { thickness } \\
/ \mathrm{m}\end{array}$ & $\begin{array}{l}\text { depth } \\
/ \mathrm{m}\end{array}$ & $\begin{array}{l}\text { stratigraphic } \\
\text { column }\end{array}$ & lithology & aquifers \\
\hline Quaternary & 5.97 & 5.97 & $=0$ & sand bed \& gravel & porous phreatic aquifer \\
\hline \multirow{20}{*}{ Triassic } & \multirow{7}{*}{73.50} & \multirow[b]{7}{*}{79.47} & \begin{tabular}{|c|}
$-\cdot-\cdot---\cdot$ \\
\end{tabular} & \multirow{7}{*}{ sandy claystone } & \\
\hline & & & ---- & & \\
\hline & & & $-\cdot----\cdot-$ & & \\
\hline & & & $--\quad--$ & & \\
\hline & & & $-\cdot----\cdot-$ & & \\
\hline & & & ---- & & \\
\hline & & & $-\cdot-\cdot----$ & & \\
\hline & \multirow{9}{*}{97.20} & & $\begin{array}{l}\cdot \cdot \cdot \cdot \cdot \\
\cdot \cdot \cdot \cdot \cdot\end{array}$ & \multirow{9}{*}{ coarse sandstone } & \\
\hline & & & $\cdot \quad \cdot \quad \cdot$ & & \\
\hline & & & $\cdot \begin{array}{llll}\cdot & \bullet & \bullet & \bullet \\
\end{array}$ & & \\
\hline & & & $\cdot \cdot \cdot \cdot$ & & \\
\hline & & & $\because \cdot{ }^{\circ} \cdot{ }^{\prime} \cdot$ & & \\
\hline & & & $\cdot \cdot \cdot \cdot \cdot \cdot$ & & \\
\hline & & & $\cdot \bullet \cdot \bullet \cdot \bullet \cdot \bullet$ & & \\
\hline & & & $\bullet \quad \bullet \quad \bullet \quad \bullet$ & & \\
\hline & & 176.67 & $\cdot \cdot \cdot \cdot \cdot \cdot$ & & \\
\hline & \multirow{2}{*}{16.07} & \multirow{2}{*}{192.74} & $--\quad--$ & \multirow{2}{*}{ sandy claystone } & \\
\hline & & & $----\cdot-\cdot$ & & \\
\hline & \multirow{2}{*}{25.05} & & $\bullet \cdot \bullet \cdot \bullet$ & \multirow{2}{*}{ coarse sandstone } & \\
\hline & & 217.79 & $\begin{array}{l}\cdot \cdot \cdot \cdot \cdot \\
\cdot \cdot \cdot \cdot\end{array}$ & & \\
\hline \multirow{8}{*}{ Permian } & \multirow{4}{*}{50.61} & \multirow[b]{4}{*}{268.40} & $---\quad-\cdot-$ & \multirow{4}{*}{$\begin{array}{l}\text { sandy claystone } \\
\text { sandstone } \\
\text { No.1 coal seam }\end{array}$} & \multirow{4}{*}{ fractured confined aquifer } \\
\hline & & & $----\cdot-\cdot$ & & \\
\hline & & & $\begin{array}{c}---1 \\
-----1\end{array}$ & & \\
\hline & & & $\begin{array}{c}-\cdot-\cdot- \\
-\cdot---\cdot-\end{array}$ & & \\
\hline & 8.32 & 276.72 & $-=-\overline{-1}$ & $\begin{array}{l}\text { sandy claystone } \\
\text { No. } 2 \text { \& } 3 \text { coal seam }\end{array}$ & \\
\hline & & & $\begin{array}{l}---1- \\
----\cdot-\end{array}$ & coarse sandstone & \\
\hline & 30.08 & 306.80 & $\bullet \bullet \cdot$ & No.8 coal seam & fractured confined aquifer \\
\hline & 14.45 & 321.25 & $\cdot \cdot \cdot \cdot \cdot$ & $\begin{array}{l}\text { claystone } \\
\text { No. } 9 \text { \& } 10 \text { coal seam }\end{array}$ & \\
\hline \multirow{8}{*}{ Carboniferous } & & & $\begin{array}{c}---1- \\
----\cdot-\end{array}$ & sandy claystone & \multirow{4}{*}{ fractured confined aquifer } \\
\hline & 34.19 & & $-----\overline{-}$ & claystone & \\
\hline & & 355.44 & $\begin{array}{l}-1-7-1 \\
-1- \\
----1-\end{array}$ & No.12 coal seam & \\
\hline & \multirow{3}{*}{34.18} & \multirow{3}{*}{389.62} & $--\quad-.-$ & \multirow{3}{*}{$\begin{array}{l}\text { sandy claystone } \\
\text { sandstone } \\
\text { No.14 } 1516 \& 17 \text { coal seam }\end{array}$} & \\
\hline & & & ------- & & location of the water inrush \\
\hline & & & $--=-2$ & & \multirow{3}{*}{ fractured confined aquifer } \\
\hline & \multirow{2}{*}{18.11} & \multirow[b]{2}{*}{407.73} & $\because \cdot \cdot \cdot \cdot \cdot$ & \multirow{2}{*}{$\begin{array}{l}\text { sandstone } \\
\text { No.18 \& } 19 \text { coal seam }\end{array}$} & \\
\hline & & & T 17 & & \\
\hline Ordovician & $>200.0$ & & | & karst limestone & karst confined aquifer \\
\hline
\end{tabular}

Figure 4. Strata and aquifer distribution at the Luotuoshan coal mine.

The fractured sandstone-confined aquifers comprise four parts. Their properties are detailed as follows. As shown in Figure 4, the first is located in Late and Middle Permian strata overlying the No. 1 coal seam. Its thickness varies from $144 \mathrm{~m}$ to $487 \mathrm{~m}$. The elevation of the groundwater table is about $+1262.25 \mathrm{~m}$. The second is located in Early Permian strata between the No. 3 and the No. 8 coal seams. Its thickness is about $15 \mathrm{~m}$. The elevation of the groundwater table varies from $+1295.93 \mathrm{~m}$ to $+1272.12 \mathrm{~m}$. The third is located in the Carboniferous strata between the No. 10 and the No. 16 coal seams. Its thickness is about $11.5 \mathrm{~m}$. The elevation of the groundwater table varies from $+1210.67 \mathrm{~m}$ to $+1274.02 \mathrm{~m}$. The fourth is located in the Carboniferous strata between the No. 16 and the No. 18 coal seams. Its thickness is about $15 \mathrm{~m}$. The elevation of the groundwater table is about $+1276.50 \mathrm{~m}$.

Finally, the karst-confined aquifer is located in the Ordovician limestone. Its thickness is bigger than $200 \mathrm{~m}$. Elevation of the groundwater table varies from $+1117.75 \mathrm{~m}$ to $+1070 \mathrm{~m}$. The water-abundance 
is proportional to the porosity. It possesses a high water-abundance in the porous area and a low water-abundance in the intact area.

The average vertical distance between the No. 16 coal seam and top of the Ordovician limestone is only about $20 \mathrm{~m}$. As a result, the top of the karst aquifer will probably heave because of the goaf formed during the underground coal mining. Furthermore, groundwater in the karst aquifer will probably rush into the goaf when any fractures induced by the heave meet the goaf. The probable groundwater inrush will seriously damage the underground mining.

\section{The Accident Sequence and the Rescue Operations}

At 5:50, 1 March 2010, a jet stream gushed out from a blast hole in the heading face of the air return gallery in the No. 16 coal seam. It continued for approximate $5 \mathrm{~s}$.

At 6:10, more jet streams appeared from 5-6 blast holes. The maximum diameter of the water streams was approximate $20 \mathrm{~cm}$. Meanwhile, a small part of the floor heaved 0.1-0.3 $\mathrm{m}$. This part was 10-m long and 1.2-m wide. As shown in Figure 3, it originated from a location where the distance between it and the heading face was approximate $26 \mathrm{~m}$. An obvious fracture appeared at the boundary of the heaved part. The fracture was approximate 10-m long, 4-cm wide and 5-cm deep.

At 6:30, more and more blast holes were filled with gushing streams. The height of the heaved part was increasing.

At 7:20, a great amount of groundwater gushed out and galleries in the No. 16 coal seam were flooded. The depth of the accumulated water reached approximately $1 \mathrm{~m}$. At that moment, miner evacuation and rescue operations were initiated immediately.

At 8:05, the accumulated groundwater reached bottom of the vertical air return shaft with an elevation of $+893.50 \mathrm{~m}$.

At 14:00, the elevation of the accumulated groundwater reached $+1079.05 \mathrm{~m}$. Galleries located in No. 16 and No. 9 coal seams were almost submerged.

At 24:00, 3 March, the maximum elevation of the accumulated groundwater table in the pit reached $+1093.00 \mathrm{~m}$, as Figure 3 illustrates.

During the post-accident rescue, large-scale drainage was performed. Meanwhile, surface boreholes were conducted to connect the galleries for probable survivors. At 09:24, 7 March, six boreholes connected the galleries in the No. 9 coal seam with an elevation of $+1100 \mathrm{~m}$. Unfortunately, no survivors was found. After that, the drilling ended. Grouting and continuous drainage were conducted for the coalmine recovery. The grouting ended on 28 April. The drainage ended on 10 May. Underground rescue started on 14 April and ended on 7 May. Finally, 32 drowned miners were found in the pit.

\section{Characteristics and Mechanism of the Groundwater Inrush}

\subsection{The Source}

According to recall of some of the miners who escaped from the flooded pit and post-accident site-reconnaissance, the groundwater inrush originated from the floor heave, in the air return gallery in the No. 16 coal seam, as Figure 5 illustrates.

The inburst groundwater is from the Ordovician limestone aquifer, which underlies the No. 16 coal seam. The reasons are as follows: Firstly, according to the hydrochemical test results, the properties of the inburst groundwater are similar to those of the nearby Ordovician karst groundwater, as shown in Table 1. Secondly, based on monitoring records of tables of the accumulated groundwater in the pit and drainage flow rates in the post-accident rescue, as Figure 6 illustrates, variations of the two curves show that the inburst groundwater behaved with obvious characteristics of the Ordovician karst groundwater. This conclusion is supported by the following facts: (1) During the initial drainage period, i.e., the $a-b$ segment in Figure 6, the groundwater table still increased slowly even if the drainage flow rate remained a certain constant scale. This showed that the groundwater in the pit 
was recharged strongly and continuously. The recharge behaved with obvious characteristics of the Ordovician karst groundwater. (2) The groundwater table in the pit decreased obviously on increasing of the drainage flow rate. Then the decrease developed slowly because of the increased recharge, i.e., $b-c$ and $f-g$ segments in Figure 6. It behaved with obvious characteristics of the Ordovician karst groundwater, too. (3) The groundwater table recovered obviously on decreasing of the drainage flow rate, i.e., $c-d, e-f$ and $h$ - $i$ segments in Figure 6 . It showed that the groundwater in the pit was recharged strongly and continuously. The recharge behaved with obvious characteristics of the Ordovician karst groundwater, too.

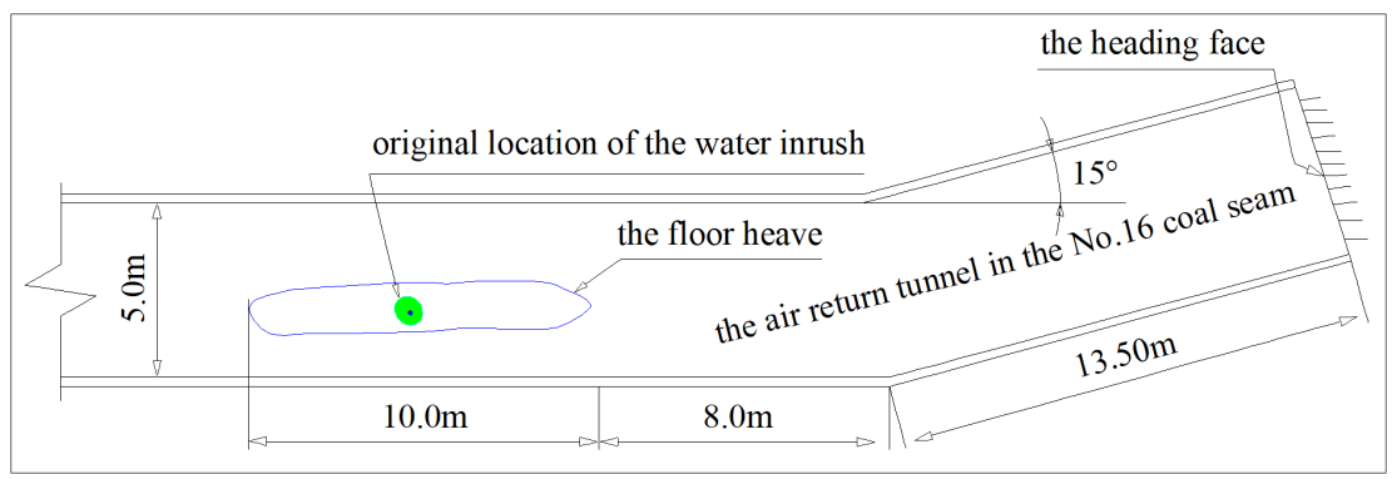

Figure 5. A plane sketch of the origin of the groundwater inrush.

Table 1. Hydrochemical properties of the Ordovician karst groundwater from different coalmines/places.

\begin{tabular}{ccccc}
\hline Sampling Site & $\begin{array}{c}\text { Drained-out } \\
\text { Groundwater } \\
\text { during the } \\
\text { Post-Accident } \\
\text { Rescue }\end{array}$ & $\begin{array}{c}\text { The Ordovician Karst } \\
\text { Groundwater Sampled in } \\
\text { the Galleries of the No.16 } \\
\text { Coal Seam before the } \\
\text { Accident }\end{array}$ & $\begin{array}{c}\text { The Ordovician } \\
\text { Karst } \\
\text { Groundwater } \\
\text { Sampled at a } \\
\text { Nearby Coalmine }\end{array}$ & $\begin{array}{c}\text { The Ordovician } \\
\text { Karst Groundwater } \\
\text { Sampled in a nearby } \\
\text { Supply Well }\end{array}$ \\
\hline Sampling date & 4 March 2010 & 1 January 2008 & 6 March 2010 & 7 March 2010 \\
\hline Total hardness & 284.50 & 266.24 & 399.3 & 494.60 \\
\hline $\begin{array}{c}\text { Carbonate } \\
\text { hardness }\end{array}$ & 194.88 & 199.18 & 220.2 & 179.64 \\
\hline $\mathrm{Ca}^{2+}$ & $65.64 / 3.27$ & $57.11 / 2.85$ & $93.2 / 4.65$ & $116.35 / 5.81$ \\
\hline $\mathrm{Mg}^{2+}$ & $29.29 / 2.41$ & $30.02 / 2.47$ & $40.5 / 3.33$ & $49.97 / 4.11$ \\
\hline $\mathrm{Na}^{+}$ & $85.45 / 3.72$ & $73.16 / 3.18$ & $91.2 / 3.97$ & $84.02 / 3.65$ \\
\hline $\mathrm{K}^{+}$ & $4.77 / 0.12$ & $3.18 / 0.08$ & $5.50 / 0.14$ & $3.50 / 0.09$ \\
\hline Total cation & $185.25 / 9.53$ & $163.47 / 8.58$ & $230.4 / 12.09$ & $253.81 / 13.66$ \\
\hline $\mathrm{Cl}^{-}$ & $95.42 / 2.69$ & $80.83 / 2.28$ & $108.1 / 3.05$ & $94.06 / 2.67$ \\
\hline $\mathrm{SO}_{4}^{-}$ & $141.26 / 2.94$ & $87.42 / 1.82$ & $194.1 / 4.14$ & $350.52 / 7.30$ \\
\hline $\mathrm{HCO}_{3}^{-}$ & $237.61 / 3.89$ & $242.85 / 3.98$ & $268.5 / 4.40$ & $219.01 / 3.59$ \\
\hline $\mathrm{F}^{-}$ & $0.65 / 0.03$ & $0.43 / 0.02$ & 0.50 & $1.02 / 0.05$ \\
\hline Total anion & $474.41 / 9.53$ & $427.32 / 8.35$ & $580.70 / 11.65$ & $664.36 / 13.65$ \\
\hline $\mathrm{PH}^{-}$value & 6.9 & 7.5 & 7.5 & 7.82 \\
\hline Total solid & 700 & 600.12 & 684.95 & 429.87 \\
\hline $\begin{array}{c}\text { Sample } \\
\text { temperature }\end{array}$ & $20.5{ }^{\circ} \mathrm{C}$ & $25{ }^{\circ} \mathrm{C}$ & $19{ }^{\circ} \mathrm{C}$ & $20{ }^{\circ} \mathrm{C}$ \\
\hline
\end{tabular}




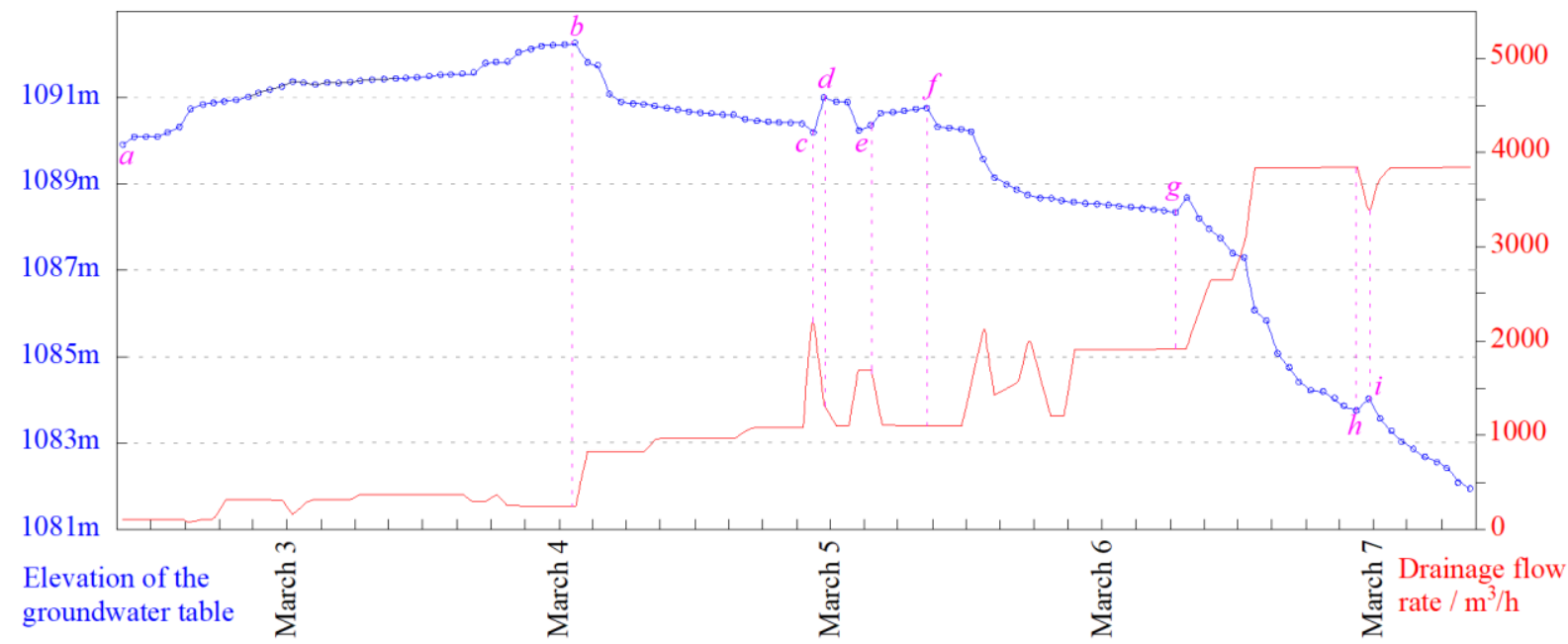

Figure 6. Monitoring records of the groundwater table and the drainage flow rate in the post-accident rescue.

Furthermore, according to volume of the flooded galleries and shafts, i.e., approximate $67,000 \mathrm{~m}^{3}$, from 7:30 to 8:40 on 1 March, an estimated peak flow rate of the groundwater inrush was $60,036 \mathrm{~m}^{3} / \mathrm{h}$. It behaved an obvious characteristic of the Ordovician karst groundwater inrush.

\subsection{The Passage and the Water Inrush Mechanism}

With respect to the passage, as shown in Figure 7, a water-conductive karst collapse column was uncovered by some boreholes drilled after the site rescue. The collapse column, the gallery excavation and the high-pressure groundwater induced together the passage to form gradually.

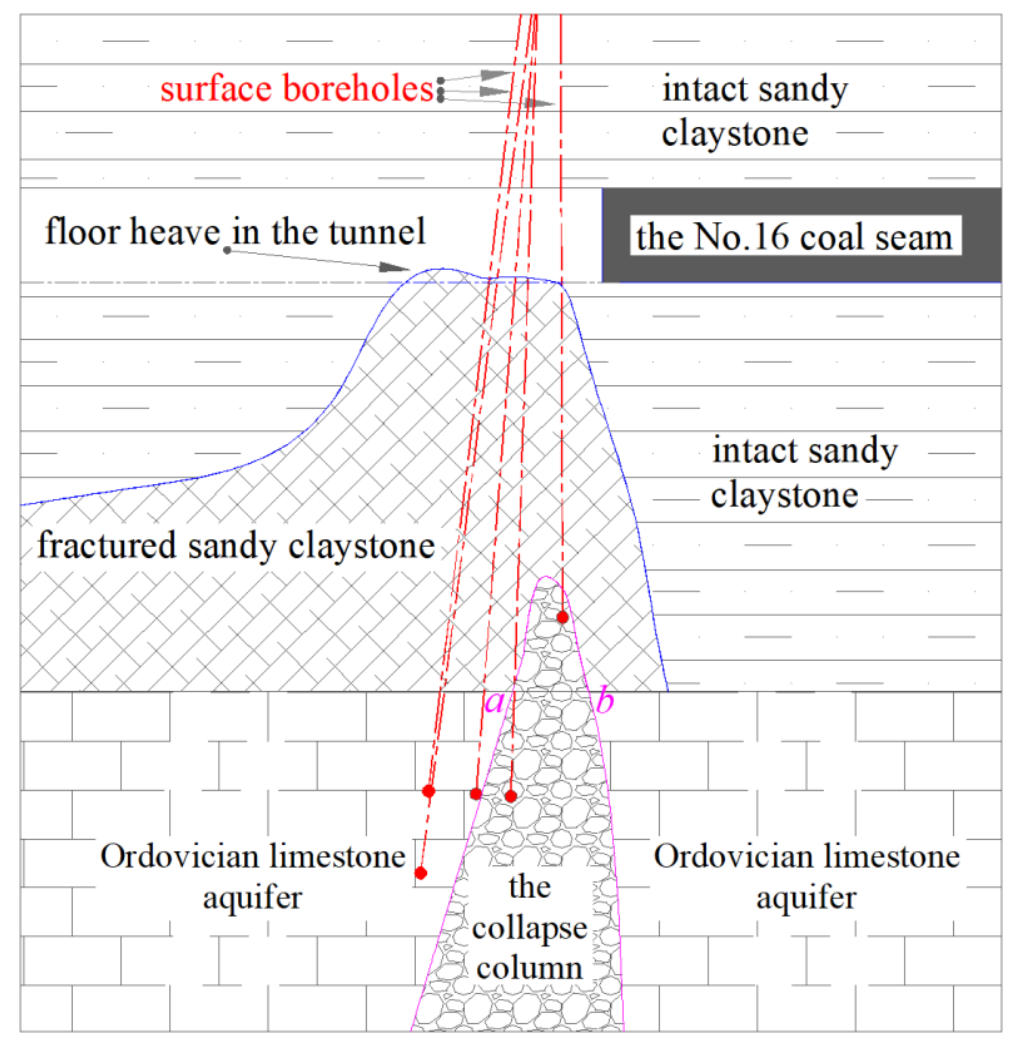

Figure 7. Distribution sketch of the passage of the inburst groundwater. 
Firstly, the vertical distance between the floor of the No. 16 coal seam and the top of the Ordovician limestone was approximate $34 \mathrm{~m}$. However, according to the site tests and theoretical calculations, the safe thickness of the aquiclude was approximate $11.5 \mathrm{~m}$. Therefore, the karst groundwater had no way to touch the floor of the No.16 coal seam under tectonic influence conditions or absent a geological anomaly. Secondly, based on the borehole surveying and the related analysis, as Figure 7 illustrates, excavation of the air-return gallery of the No.16 coal seam triggered the underlain sandy claystone to fracture. Therefore, the floor heave formed gradually. Furthermore, the high-pressure groundwater accumulated in the water-conductive collapse column induced the overlying sandy claystone to fracture, too. The fractured sandy claystone expanded gradually and eventually the water-conductive passage formed. As a result, the high-pressure groundwater in the Ordovician limestone aquifer rushed into the galleries in a large scale and the disastrous accident occured quickly.

According to the drilling surveys, the width of the top of the collapse column, $a-b$ segment in Figure 7, was approximately $10 \mathrm{~m}$. As shown in Figure 8, core samples in the collapse column are seriously fractured, poorly sorted and poorly rounded. They present obvious properties of the collapse mass.

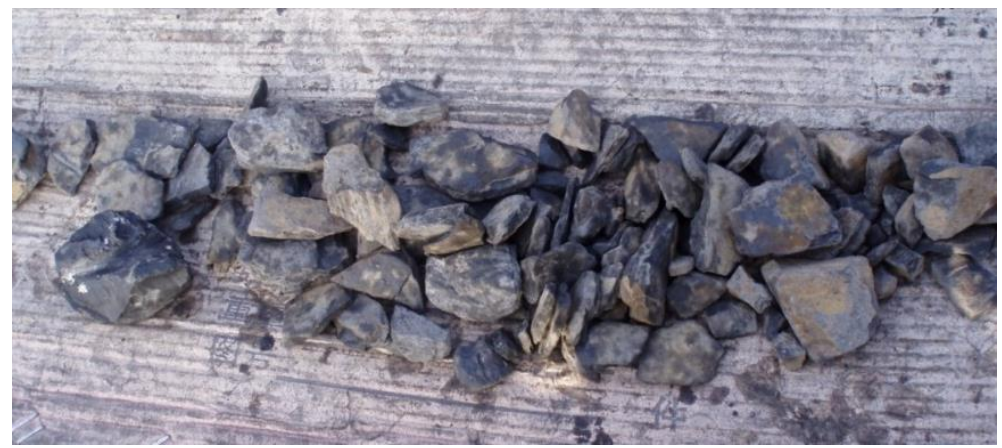

Figure 8. Core samples obtained from the collapse column.

\section{Causes of the Accident}

First of all, the gallery excavation contrary to related regulations triggered the disastrous accident. The excavation was conducted under conditions where the hydrogeological environment was not fully recognized. No detailed distribution of the collapse column underlying the No. 16 coal seam was detected and confirmed during the excavation. The conduct was against mandatory items in Regulations on Coal Mine Water Hazard Controlling issued by National Coal Mine Safety Administration in 2009. According to the regulations, comprehensive exploration must be carried out before a gallery's construction. Furthermore, effective countermeasures such as grouting, drainage, reservation of waterproof coal (rock) pillar, can be used to control a potential groundwater inrushes triggered by the appearance of a geological anomaly or complications due to hydrogeological conditions. However, in this case the necessary exploration to secure the gallery excavation was not conducted. Therefore, high-pressure groundwater accumulated in the collapse column and the gallery excavation, which caused the redistribution of the in situ stress that contributed to progressive fracturing in the floor of the No. 16 coal seam. Eventually, an intensive passage formed consisting of the fractures and the collapse column. The high-pressure groundwater from the underlying Ordovician limestone aquifer rushed into the galleries immediately and strongly.

Second, some other technical mistakes also contributed the disastrous accident. They are detailed as follows: (1) an immediate response was absent. From 5:50 to 7:20 on March 1, i.e., from the time obvious signals appeared to that of a great amount of groundwater inrushing, an evacuation order was not given quickly. The delayed retreat was against the related regulations. Furthermore, it caused great disastrous damage. (2) Precision of the hydrogeological achievements didn't secure the gallery excavation and underground mining in the future completely. Actually, some geological explorations were conducted and finished during other galleries' excavation. However, no geological anomaly, such 
as a collapse column, was found. Most of all, during the excavation, water-abundance exploration and potential release tests were not carried out although they were the most effective measures to secure the excavation.

\section{Conclusions and Suggestions}

On 1 March 2010, a disastrous groundwater inrush occurred at the Luotuoshan coal mine in Wuhai, Inner Mongolia, China. The accident caused great damage, including 32 deaths and direct economic losses of over 48 million yuan.

The groundwater inrush originated from the floor heave in the air return gallery in the No. 16 coal seam. Results of the hydrochemical tests and relevant records showed that the inburst groundwater was from the Ordovician limestone aquifer underlying the No. 16 coal seam. An estimated peak flow rate of the groundwater inrush was $60,036 \mathrm{~m}^{3} / \mathrm{h}$. It behaved with obvious characteristics of an Ordovician karst groundwater inrush.

Results of subsequent drilling explorations and related theoretical analysis showed that the passage consisted of the fractures formed in the sandy claystone underlying the No.16 coal seam and the collapse column developed in the Ordovician limestone. The high-pressure groundwater accumulated in the collapse column and the gallery excavation, which caused a redistribution of the in situ stress, contributing to progressive fracturing in the floor of the No. 16 coal seam. Eventually, an intensive water-conductive passage formed. The groundwater from the underlain Ordovician limestone aquifer rushed into the galleries immediately and strongly.

The gallery excavation without necessary site exploration was against relevant regulations and triggered the disastrous accident. Furthermore, the poor awareness of groundwater inrush recognition and responses also contributed to the disastrous extent of the accident.

Some important lessons can be learned from this event, as follows: Some important regulations, for example, Regulations on Coal Mine Water Hazard Controlling, must be obeyed thoroughly during underground coal mining. The awareness about groundwater inrush recognition and control must be strengthened. Some treatments must be conducted immediately on the site.

Author Contributions: Conceptualization, F.C. and Q.W.; methodology, Q.W.; validation, F.C.; formal analysis, X.C. and F.M.; investigation, X.C., F.M. and J.P.; writing-original draft preparation, F.C. and C.X.; writing-review and editing, Q.W.; visualization, F.C., C.X., F.M. and J.P.; supervision, Q.W.; project administration, Q.W.; funding acquisition, F.C. All authors have read and agreed to the published version of the manuscript.

Funding: This research was funded by the National Key Research and Development Programs of China, grant number 2017YFC0804104 \& 2018YFC1504802 and Fundamental Research Funds for the Central Universities of China, grant number 2009QD14.

Acknowledgments: We gratefully acknowledge the financial support from the National Key Research and Development Programs of China (Grant nos. 2017YFC0804104 \& 2018YFC1504802), Fundamental Research Funds for the Central Universities of China (2009QD14). We indeed appreciate the experts from the accident investigation team for their great help.

Conflicts of Interest: The authors declare no conflict of interest.

\section{References}

1. Bukowski, P. Evaluation of water hazard in hard coal mines in changing conditions of functioning of mining industry in Upper Silesian coal basin-USCB (Poland). Arch. Min. Sci. 2015, 60, 455-475. [CrossRef]

2. Dash, A.K.; Bhattacharjee, R.M.; Paul, P.S. Lessons learnt from Indian inundation disasters: An analysis of case studies. Int. J. Disaster Risk Reduct. 2016, 20, 93-102. [CrossRef]

3. Kuscer, D. Hydrological regime of the water inrush into the Kotredez coal mine (Slovenia, Yugoslavia). Mine Water Environ. 1991, 10, 93-102.

4. Polak, K.; Ro'zkowski, K.; Czaja, P. Causes and effects of uncontrolled water inrush into a decommissioned mine shaft. Mine Water Environ. 2016, 35, 128-135. [CrossRef]

5. Sammarco, O. Spontaneous inrushes of water in underground mines. Int. J. Mine Water 1986, 5, $29-42$. [CrossRef] 
6. Dumpleton, S.; Robins, N.S.; Walker, J.A.; Merrin, P.D. Mine water rebound in South Nottinghamshire: Risk evaluation using 3-D visualization and predictive modelling. Q. J. Eng. Geol. Hydrogeol. 2001, 34, 307-319. [CrossRef]

7. Kim, J.M.; Parizek, R.P.; Elsworth, D. Evaluation of fully-coupled strata deformation and groundwater flow in response to longwall mining. Int. J. Rock Mech. Min. Sci. 1997, 34, 1187-1199. [CrossRef]

8. Sammarco, O. Inrush prevention in an underground mine. Int. J. Mine Water 1988, 7, 43-52. [CrossRef]

9. Cui, F.P.; Wu, Q.; Zhang, S.; Wu, N.; Ji, Y. Damage characteristics and mechanism of a strong water inrush disaster at the wangjialing coal mine, Shanxi province, China. Geofluids 2018, 2018, 11. [CrossRef]

10. Cui, F.P.; Wu, Q.; Lin, Y.H.; Zeng, Y.F.; Zhang, K.L. Damage features and formation mechanism of the strong water inrush disaster at the daxing co mine, Guangdong province, China. Mine Water Environ. 2018, 37, 346-350. [CrossRef]

11. Li, S.; Liu, B.; Nie, L.; Liu, Z.; Tian, M.; Wang, S.; Su, M.; Guo, Q. Detecting and monitoring of water inrush in tunnels and coal mines using direct current resistivity method: A review. J. Rock Mech. Geotech. Eng. 2015, 7, 469-478. [CrossRef]

12. Qian, M.G.; Miao, X.X.; Xu, J.L. Theoretical study of key stratum in ground control. J. China Coal Soc. 1996, 1, 225-230.

13. Shi, L.; Singh, R.N. Study of mine water inrush from floor strata through faults. Mine Water Environ. 2001, 20, 140-147. [CrossRef]

14. Wu, Q.; Cui, F.P.; Zhao, S.Q.; Liu, S.Q.; Zen, Y.F.; Gu, Y.W. Type classification and main characteristics of mine water disasters. J. China Coal Soc. 2013, 38, 561-565.

15. Wu, Q.; Liu, Y.; Zhou, W.; Li, B.; Zhao, B.; Liu, S.; Sun, W.; Zeng, Y. Evaluation of water inrush vulnerability from aquifers overlying coal seams in the Menkeqing coal mine, China. Mine Water Environ. 2015, 34, 258-269. [CrossRef]

16. Zhang, J.C.; Liu, T.Q. On depth of fissured zone in seam floor resulted from coal extraction and its distribution characteristics. J. China Coal Soc. 1990, 15, 225-230.

17. Cui, F.P.; Wu, Q.; Lin, Y.H.; Zhao, S.Q.; Zeng, Y.F. Prevention and control techniques \& methods for water disasters at coal mines in China. J. Min. Sci. Technol. 2018, 3, 219-228.

18. Guo, W.J.; Liu, Y.X. Concept and application of floor water inrush coefficient. Hebei Coal 1989, $2,56-60$.

19. Wang, Z.M.; Lai, Y.W.; Duan, J.J. Application of five figure double coefficient method in water burst evaluation of beixinyao mine floor. Coal Chem. Ind. 2016, 39, 7-12.

20. Wu, Q.; Hao, X.L.; Dong, D.L. Three maps-two predictions" method to evaluate water bursting conditions on roof coal. J. China Coal Soc. 2000, 25, 60-65.

21. Wu, Q.; Zhang, Z.L.; Zhang, S.Y.; Ma, J.F. A new practical methodology of the coal floor water bursting evaluating II: The vulnerable index method. J. China Coal Soc. 2007, 32, 1121-1126. 